\title{
Mediation and Action: Shift of an Object of Study
}

\author{
Boris D. Elkonin* \\ Psychological Institute \\ of the Russian Academy of Education \\ 4 building, 9 Mohovaya Str., Moscow, 125009, Russia
}

Received 29.08.2014, received in revised form 14.09.2014, accepted 29.11.2014

The paper suggests a new notion on the object of study and practice in the modern Cultural-Historical psychology. The approach is based on the phenomenological method of analysis by versions of Husserl and Martin Heidegger. The object of the study as well as the center of practices should be mediation itself - its source and conditions, - but not the form of a consciousness (its concentration), which is understood as an objective action derivative. Mediation is carried out as a combined Intermediary Action. Conditions of its accomplishment and development are the subject of researches and practices.

Keywords: noema, apperception, higher psychical functions, interpsychic form, object action, mediation, cumulative effect, intermediary action.

Research area: pedagogy, psychology.

\section{1}

In 1978, in his monograph titled "A System Approach and a Principle of Activity" E.G. Yudin said that the psychological theory of activity would move from considering activity as an explanatory principle to considering it as an object of study.

In the same year the article "Notes on the Development of Object-Related Actions in the Early Childhood" written by D.B. Elkonin was published, and in my opinion, it contains prerequisites for the ontological and methodological shift that was mentioned by E.G. Yudin. To clarify this, it is necessary to answer the question of what was the object of study in Vygotskian psychology and what was another object born in the same psychology.

\section{2}

An answer to the question on the Object is the answer to the question of that kind of lifelike, actual situation that we cannot disregard. We cannot disregard it because of its intrigue that "calls" it to think, i.e. to emphasize, highlight, isolate and, in this sense, idealize - to become its observer. Such a Call, Noema (Husserl E. [5]), is the beginning of our (researchers') intentionality. In this Call we consciously or unconsciously believe and assert a certain situation in a status of an important life Event.

Thus, a question on the object is in assumption of which life Event do we build descriptions and explanations. Let me note that it seems that a similar Call-Event lies at the basis

(C) Siberian Federal University. All rights reserved

* Corresponding author E-mail address: belconin@bk.ru 
of our practices as well, but, as a rule, we do not grasp it, do not make it clear. ${ }^{2}$.

Here, however, we must make a pause in understanding. In the words on highlighting (assertion) a certain life content there are two accents. The first one is on what content is highlighted ("calls"). And the second one is on the fact that the content is highlighted and asserted (as "calling"), i.e. the accent is on the act of highlighting-assertion itself and the intrigue is in it, in HOW it is happening. And this "how" means that the challenge occurs not only from some content "to me", but also from "me" (with all my assumptions) to a certain situation. In everyday life we often forget about the second accent, but its achievements, conflicts and failures "whirl" around our "attitude" to its content - around how and why something we think and do is important and significant to us, but something is of minor importance.

Well, what kind of an intrigue in what situation do we manifest in the words "Meaning", "Consciousness", "Activity"? Which manifestation does "appeal" which observer to use them? Beyond these questions the words "clutch" at words and these "clutches" are endless. It is such "clutches" that characterize dispersion, i.e. the end of the cultural traditions.

\section{3}

Psychology of the end of the $19^{\text {th }}$ century is characterized by the image of Consciousness as a "space", a "centre", the focus of which is a "point" of the clear vision. There, "psychic phenomena" are collected, concentrated and combined. W. Wundt called this concentration (after Leibniz and Kant) Apperception and claimed that it is possible to create special situations, in which the effort of Apperception becomes observable. This is how the experimental psychology appeared. What was supposed by Noema, the Event that is intriguing and calling understanding? The
Event was supposed to be the bringing by the individual the life reality into manifestation (and mental life-into recollection). These were the "landscape heights" of everyday life, from which it became understandable. It is clear that it was not Wundt (Fechner, Helmholtz, Titchener and many others) who gave clarity and distinctness of vision as a centre of Consciousness, but they initiated special works on the artificial reconstruction of situations of emergence of this phenomenon, which is the experimental psychology.

So Apperception (state of a clear vision) received the status of life event - a Phenomenon, terms of which we have to understand and recreate.

Radical behaviourism contrasted Stimulation with apperception and, thus, presented the living world as a world of strong incentives that by themselves, without any human efforts, dictate the relief of everyday life. Conceptual opponents of behaviourism - Gestalt psychology - presented the world as a world of incomplete forms, the completion of which is an insight. Apperception from "being conscious" "came out" and turned out to be a creative act. A change in "dislocation", however, did not change the essence of the key question - the question of what are the conditions of recollection (Gestalt) and discretion (of something significant).

\section{4}

From the given context in the concept of L.S. Vygotsky four main statements should be distinguished.

1. A necessary condition for the transition from the dissipated into concentrated consciousness (apperception) is mediation - the valuation of your own behaviour through cultural forms - signs ${ }^{3}$. The valuation of your own behaviour is mastering it. These are the higher mental functions, as distinct from the natural 
ones, where it is not a man who masters his activity, but vice versa - the element of activity "owns" the human psyche.

2. The initial condition of valuation is formation of an intermental form of activity (behaviour). Here, a sign (word) becomes a Psychological Tool - a tool of (co)control over your own behaviour. Later, the interpsychic form turns into intrapsychic - the other person is only implicit in the construction of behaviour.

3. In the formation of the intermental form and its transformation into intrapsychic, the observer turns into a participator of activity, a "codoer". This is a requirement of an experimental and genetic method a method, only following which you can explore the origins and, therefore, the nature of Consciousness (concentrated consciousness, apperception).

4. Formation of consciousness is the overcoming the natural form of activity in the cultural one. It is exactly overcoming unlike considering the cultural form "near" with the natural one or "above" it.

Then what is the object of study, according to Vygotsky? This is a difficult question, because its concept "shows" another event, another noema unlike focused consciousness. However, to the extent where the experimental genesis, formation of valuation is completed as focused (concentrated) consciousness and, therefore, the valuation is only a means of its growing, we can say that the very object of study remains the same as in the classical psychology. In the experimental results there are symptoms of occurrence of concentrated consciousness: the one who did not remember - remembers the one who did not heed - heeds. However, some texts also have other intention. These are the fragments of behaviour descriptions in the work "A tool and a sign..." descriptions of correlations of written and inner speech in Chapter 7 of "Thinking and speaking".

\section{5}

In my opinion, the followers of the Activity Theory only intensified the classic aspect of the Vygotsky's concept. And it is quite strange: it seemed that the concept of the external objective action was introduced in order to understand how the very valuation is built, how the intermental form exists, i.e. it seemed as though the object became mediation itself. However, gnoseologization of the experimental developments, the allegation that the action is "primary" and consciousness (meaning, word) is "secondary" - "turned" the intentional act into the classical course, the course of explanation of how consciousness "occurs". Action acted as an explanatory principle, but not as an object of study, as was noted by E.G. Yudin.

And the same as in Vygotsky's studies, the results of the experimental genesis were described as the facts of the transition to the "clear vision": the one who did not see - has seen, the one who did not feel - has felt, the one who did not single out a significant relation of a class of problems has singled out. The latter, by the way, boldly defines the image of the transition from turbidity to clarity and from distraction to concentration.

\section{6}

"Notes on the Development of ObjectRelated Actions" by D.B. Elkonin is the beginning of the transition of research intentions, the shift of the object of study. This transition has been continued and strengthened in my research.

1. The object of study and practicing became the act of mediation itself.

2. To study mediation itself means identifying how a value addressed to another person (a child) in a function of a psychological tool becomes an obvious 
participant of the action and acquires a function of a sample - it becomes a support and forms a field of co-action. I stress that it is obvious to all participants, i.e. both an adult and a child - here and now rather than "before" co-action. Prior to co-action there are no significances, but there are empty word forms.

3. To study mediation itself means to identify the execution conditions of the intermental form or, using D.B. Elkonin words, a joint action.

In such study and practicing the Event and

Intrigue of the joint action act as a "node" of everyday life.

To the extent when the intentional object is the joint action, there is no place for notions of "communication", "consistency", "intermental form", "co-existence" as existing arches; there is no place for notions of culture as some reality that is already existing. There is a place for understanding the conditions where words, images and gestures become support of activity.

Due to some circumstances, many researchers assume that the communication and addressing occur by themselves, in a natural way and therefore it is possible to speak of them as facts of everyday life. I believe that the implementation of addressing is as exclusive, as a creative act.

According to the observations of D.B. Elkonin over the deployment of object-related actions in early childhood ([13], [14]), as well as the experience of some forming experiments ([12]), there are two main conditions for the occurrence and recreation of the joint action.

1. Mediation by an adult of a child's behaviour built as their joint action (intermental form) is carried out provided that: a) the child identifies and emphasizes words, gestures, samples of the adult and b) emphasizes them as a "reverse" challenge to the adult, thereby claiming, showing the importance of the situation of the adult's address.

2. Mediation is carried out provided that the child asserts samples of the action and the situation of interaction by the required content of the sample itself, i.e. by its very corporeity. In the material of corporal efforts and their functional systems the child is experiencing and testing the meanings of words, gestures, samples of the adult. The corporeity of the child becomes a screen of the adult's meaningful word - amplifies, reflects and returns the adult the value of his word.

It is important to emphasize that I intone the word "challenge" in opposition to the "implementation" and I believe that the challenge, through the desired action itself or, as it often happens, through the action opposite to the required one, is evidence of the testing of the word-sample ${ }^{4}$, and illustration of its recreation and "reproduction". This is the formation of meaning and assertion of significance.

I call such an action Mediatory. Mediatory action is a joint action, the purpose of which is the production of the sign's value and assertion of the mutuality situation. The mediatory action is completed within the meaning, but not within a thing. The intrigue of the mediatory action, its connectedness is the intentional object of Vygotskian psychology, the studied life Event.

\section{7}

The given idea of the intermental form requires another understanding of completing the experimental genesis. The completeness is not just a recollection in solving the problem.

For example, the inner speech is not just a "mental plan" of speaking or writing. It is not even a design or a plan of a statement separated from the statement itself - its estimated "part". 
Using the tip of L.S. Vygotsky ${ }^{5}$ (as well as Yu.M. Lotman and M.M. Bakhtin), it can be argued that the internal speech returns into the statement as its rhythm - the systematic testing of the accent and intonation of the statement, i.e. highlighting its meaning and a play with it ${ }^{6}$. The idea and the plan do not determine the implementation, but are played and replayed in it; played from the implementation itself. Only in this case we can say that the internal speech became a support of the action (statement).

The "internal" action cannot be separated from the "external" one, but is "challenged" (screened) by the external action and returned in it as an emphasis of its field, as highlighting the key, transition points in this field. That is how I understand the concept of a "functional field" introduced by P.G. Nezhnov [9].

Concluding the paper let me accent several points.

- The subject of the study of the modern cultural-historical concept is a Mediatory action. There is consciousness in a joint action7.

- Mediation must be understood and built as birth and recreation of the Action. That is how the connection of mediation and development are carried out.

- Human development is the creation and transformation of the Mediation Action.

1 Heidegger said almost the same in his work "What is called thiking?", playing upon the understanding of thinking as the response to the "challenge"[11].

2 The same is with "Culture", if it is interpreted not as an abstract norm, but as a system of accents, methods of separation of the "key points" in everyday life.

3 This implies that culture is not an "environment", but an "operator" of behavior.

4 See the examples [13]

5 In Chapter 7 of "Thinking and speaking"

6 According to the developments of L.A.Ryabinina et al., intonation and rhythmic structure of a statement is a way to master conscious reading and writing. In the laboratory "Psychology ofthe younger schoolchild" of the Institute of Psychology similar developments for groups of children preparing for school are conducted by N.Yu.Mangutova.

7 It is in this context that I understand research works of V.V.Rubtsov of the late 70s and early 80s [10]. Research works of action coordination types - types of consistency - were built in a different intention than the studiesof a joint action as the beginning of the new psychological formation of educational activity (analysis, reflection, planning). In these studies, the "new formation" was a joint action itself.

\section{References}

1. Arkhipov B.A., Ekonin B.D. Language of the anthropotechnical (mediatory) action. "Antropopraksis", Yearbook of the Humanities, 2011.

2. Bakhtin M.M. Questions of Literature and Aesthetics. M.: Fiction, 1975.

3. Vygotsky L.S. Collection of works: in 6 volumes. Vol. 2, 3, 6. M.: Pedagogy, 1982-1984.

4. Galperin P.Ya. Psychology as an objective science. M.: Institute of Applied Psychology. Voronezh: NPO "Modek", 1998.

5. Husserl E. Crisis of European Sciences and Transcendental Phenomenology. Saint-Petersburg: Vladimir Dal, 2004.

6. Zaporozhets A.V. Development of voluntary motions. M.: Publishing House of the Academy of Pedagogical Sciences of the RSFSR, 1960.

7. Leontiev A.N. Problems of development of the mind. M.: Moscow University Publishing House, 1981.

8. Lotman Yu.M. The structure of the artistic text. M.: Arts, 1970.

9. Nezhnov P.G. Mediation and spontaneity in the model of "cultural development". Bulletin of Moscow University, Ser. 14, Psychology, 2007, No. 1. 
10. Rubtsov V.V. Organization and development of joint actions of children in the learning process. M.: Pedagogy, 1987.

11. Heidegger M. What is called thinking? M.: Publishing House "Territoriya budushchego", 2006.

12. Elkonin B.D. Mediation. Action. Development. Izhevsk: Publishing House "ERGO", 2010.

13. Elkonin B.D. Event action. (Notes on the development of object-related actions 2). CulturalHistorical Psychology, 2014, No. 1.

14. Elkonin D.B. Selected psychological works. M.: Pedagogy, 1989.

15. Yudin E.G. Sistemniy podkhod i printsip deyatelnosti [A system approach and a principle of activity]. M.: "Nauka", 1978.

\title{
Опосредствование и действие: сдвиг объекта изучения
}

\author{
Б.Д. Эльконин \\ Психологический институт \\ Российской академии образования \\ Россия, 125009, Москва, ул. Моховая, 9, стр. 4
}

В статье предложено новое представление об объекте изучения и практикования 6 современной культурно-исторической психологии. Подход основан на феноменологическом способе анализа в версиях Э. Гуссерля и М. Хайдеггера. Объектом изучения и иентром практик должно стать само опосредствование - его исток и условия, - а не форма сознания (его концентрация), понятая как производная от предметного действия. Опосредствование осуществляется как совокупное посредническое действие. Условия его выполненности и развертывания - предмет исследований и практик.

Ключевые слова: ноэма, апперцепџия, высшие психические функции, интерпсихическая форма, предметное действие, опосредствование, совокупное действие, посредническое действие.

Научная спещиальность: 13.00.00 - педагогические науки, 19.00.00-nсихологические науки. 